\title{
Identifikasi Pneumonia Pada Citra Rontgen Paru Menggunakan Metode Power-Law Trans
}

\author{
Kadek Suarjuna Batu Bulan ${ }^{1}$, Ridwan Rismanto \\ 1,2 Jurusan Teknik Informatika, Politeknik Negeri Malang \\ $\underline{{ }^{1} \text { kadeksuarjuna87@ polinema.ac.id, }{ }^{2} \text { rismanto@ polinema.ac.id }}$
}

\begin{abstract}
Abstrak
Pneumonia adalah proses infeksi akut yang mengenai jaringan paru-paru (Alveoli), yang dapat disebabkan oleh infeksi jasad renik atau bakteri. Deteksi penyakit Pneumonia dilakukan melalui tanda-tanda klinis uji laboratorium dan foto x-ray paru. Penelitian ini menggunakan beberapa langkah dari pengolahan citra, seperti Power-law trans, Gabor Wavelet dan Boundary. Tujuan utama dari langkah tersebut adalah untuk mengidentifikasi infiltrate dari citra X-Ray paru-paru manusia dan menentukan klasifikasi infiltrate. Hasil penelitian mengindikasikan klasifikasi dari penyakit pneumonia menjadi normal, pneumonia ringan, dan pneumonia kronik. Pengujian dilakukan pada lima puluh citra dengan spesifikasi yang berbeda. Dari hasil pengujian tersebut, menunjukkan bahwa equivD dan perimeter rata-rata infiltrate ditiap citra yang bernilai dibawah 30 diidentifikasi sebagai penyakit pneumonia. Diidentifikasi pneumonia kronik apabila rata-rata equivD dan perimeter infiltrate diatas 30. Untuk identifikasi normal apabila centroid, equivD, perimeter dan roundness tidak ada. Validitas sistem dinilai dengan cara menghitung nilai TP, TN, FP, dan FN sehingga di dapatkan Sensitivity dari metode ini adalah 94,3\% dan Specificity dari sistem ini adalah $100 \%$.
\end{abstract}

Kata kunci : power-law trans, pneumonia, gabor wavelet dan boundary

\section{Pendahuluan}

Pneumonia adalah proses infeksi akut yang mengenai jaringan paru-paru (Alveoli), yang dapat disebabkan oleh infeksi jasad renik atau bakteri. virus, maupun riketsia, dan disertai dengan radang parenkrim paru. Pneumonia dapat timbul di berbagai daerah di paru-paru juga bisa ditandai adanya infiltrat pada paru-paru yang bisa dilihat dengan foto rontgen. Pneumonia merupakan penyakit yang umumnya terjadi pada semua kelompok umur, diketahui penyebab kematian terbesar terjadi pada orang tua dengan diagnosis penyakit Pneumonia kronis.

Hasil Survei Kesehatan Rumah Tangga Depkes tahun 2001, menunjukkan penyakit infeksi saluran napas bawah menempati urutan ke-2 sebagai penyebab kematian di Indonesia. Di dunia pneumonia merupakan masalah kesehatan karena angka kematiannya sangat tinggi, tidak saja di negara berkembang tetapi terdapat juga di negara maju seperti Amerika, Kanada dan negara-negara Eropa lainnya. Deteksi penyakit Pneumonia dilakukan melalui tanda-tanda klinis uji laboratorium dan foto $x$-ray paru. Tanda-tanda klinis dan foto paru dengan $x$-ray merupakan cara yang umum dilakukan oleh dokter untuk mendiagnosis pasien penderita penyakit pneumonia.

Pada citra paru-paru dapat diketahui pula jenis penyakit pernafasan yang lain seperti asma, TBC, kelenjar getah bening dan kanker paru-paru. Sehingga terdapat kemungkinan perbedaan pendapat oleh para radiolog dalam memutuskan atau mendiagnosa suatu penyakit karena radiolog mempunyai pengalaman yang berbeda-beda dan terkadang terdapat unsur menduga-duga. Untuk riset mutakhir ini dalam membuat sistem akan di damping oleh pakar yaitu dokter paru dari rumah sakit saiful anwar malang dengan data latih maupun data uji yang akan di proses dengan beberapa metode yaitu power-law trans, gabor wavelet dan boundary yang disetiap metode mempunyai nilainilai untuk menentukan infiltrate diparu-paru sesuai diagnosis dari pakar.

Penelitian ini bertujuan membuat suatu program bantu untuk identifikasi penyakit pneumonia. Foto paru hasil dari $x$-ray merupakan citra dua dimensi yang dapat diolah menjadi data citra digital dan dianalisis menggunakan teknik pengolahan citra digital. Ekstraksi ciri informasi paru-paru adalah kerangka acuan yang dapat menunjukkan posisi daerah fokus dan mendapatkan hasil profesional pengolahan citra rontgen di bidang pengolahan citra medis berdasarkan fitur analisis penyakit pneumonia dengan metode power-law trans. Citra paru-paru yang telah di proses dengan meningkatkan kualitas citranya menggunakan metode power-law trans. kemudian dilanjutkan dengan klasifikasi penyakit pneumonia berdasarkan informasi dari dokter. Penelitian ini untuk pengenalan penyakit pneumonia yang berfungsi membantu mengurangi suatu perbedaan pendapat dalam mendiagnosis penyakit pneumonia yang dilakukan oleh para radiologi. 
2. State of The Art

\begin{tabular}{|c|c|c|}
\hline No & Judul & Ringkasan \\
\hline 1 & $\begin{array}{l}\text { Klasifikasi } \\
\text { Pneumonia } \\
\text { menggunakan } \\
\text { Convolutional } \\
\text { Neural Network } \\
\text { (william christanto s, } \\
\text { 2018) }\end{array}$ & $\begin{array}{l}\text { Metode yang } \\
\text { diajukan memiliki } \\
\text { kemampuan dalam } \\
\text { mengidentifikasi } \\
\text { pneumonia yang } \\
\text { baik dengan akurasi } \\
\text { sebesar } 83,3 \% \text {. }\end{array}$ \\
\hline 2 & $\begin{array}{lr}\text { Analisis } & \text { Faktor } \\
\text { Risiko } & \text { Yang } \\
\text { Berhubungan } & \\
\text { Dengan } & \text { Kejadian } \\
\text { Pneuomonia } & \text { Pada } \\
\text { Anak Balita } & \text { Di } \\
\text { RSUD } & \text { Pasar Rebo } \\
\text { Jakarta } & \text { (Susanti } \\
\text { Hartanti, } 2011\end{array}$ & $\begin{array}{l}\text { Desain yang } \\
\text { digunakan adalah } \\
\text { cross sectional } \\
\text { dengan } 138 \text { sampel } \\
\text { dan hasilnya regresi } \\
\text { logistik didapatkan } 4 \\
\text { faktor risiko yaitu } \\
\text { usai balita, riwayat } \\
\text { pemberian ASI, } \\
\text { status balita dan } \\
\text { Kebiasaan Merokok. }\end{array}$ \\
\hline 3 & $\begin{array}{l}\text { Identifikasi Faktor- } \\
\text { Faktor yang } \\
\text { Mempengaruhi } \\
\text { Pneumonia pada } \\
\text { Balita di Surabaya } \\
\text { Menggunakan } \\
\text { Geographically } \\
\text { Weighted Negative } \\
\text { Binomial Regression } \\
\text { (Ratnajulie } \\
\text { Yatnaningtyas, dkk) }\end{array}$ & $\begin{array}{l}\text { Hasil pemodelan } \\
\text { menunjukkan bahwa } \\
\text { terdapat variabel } \\
\text { yang bersifat lokal } \\
\text { yang mempengaruhi } \\
\text { pneumonia dan } \\
\text { membentuk } \\
\text { kelompok sebanyak } \\
\text { sembilan kelompok. }\end{array}$ \\
\hline
\end{tabular}

\section{Metode Penelitian}

\section{A. Data Penelitian}

Data berupa foto rontgen pneumonia yang diambil dari laboratorium radiologi rumah sakit Saiful Anwar, Malang, Indonesia yang telah di diagnosis oleh dokter. Foto rontgen tersebut telah diklasifikasikan berdasarkan jenis pneumonia yaitu normal, ringan dan kronik. Foto rontgen diambil dengan resolusi maksimum 500x500 pixel. Jumlah foto rontgen yang digunakan pada penelitian ini adalah 50 citra. Gambar 1 menunjukkan contoh dari salah satu data yang digunakan.

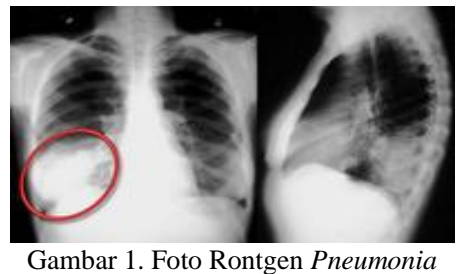

Pada gambar 1 terlihat sebuah infiltrate yang ada pada lobus kanan, komponen tersebut merupakan informasi terpenting untuk didiagnosis. Untuk mengetahui pneumonia ringan atau kronik dapat diketahui dari besar kecilnya infiltrat yang terdapat pada paru-paru.

Dalam penelitian ini terdapat analisis proses dalam memperbaiki kualitas citra hingga diketahui bagaimana hasil diagnose citra foto rontgen paruparu yang didalamnya terdapat penyakit Pneumonia. Proses awal dapat dilihat pada Gambar 2.

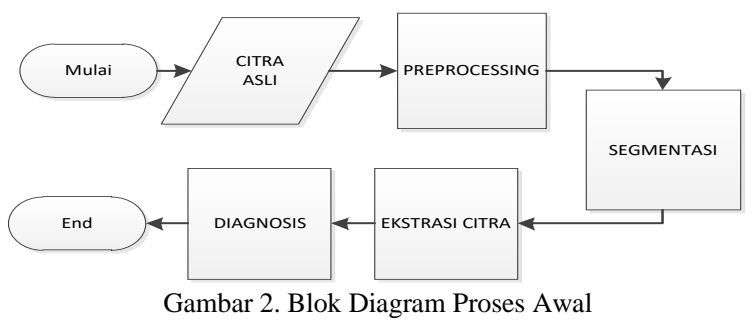

Proses ini melibatkan beberapa langkah yang berfungsi untuk memperbaiki kualitas foto rontgen yang didalamnya terdapat penyakit pneumonia.

a. Input citra yang berfungsi untuk memasukkan citra berupa foto rontgen berformat jpg, tif dan bmp.

b. Preprocessing berfungsi untuk memulai proses memperbaiki kualitas citra (image Enhancement) dengan beberapa metode sehingga mendapakan hasil citra yang lebih baik.

c. Segmentasi citra berdasarkan tekstur berguna untuk mengetahui bagaimana bentuk keteraturan pola-pola tertentu yang terbentuk dari susunan pixel-pixel dalam citra, sehingga bagian masingmasing di paru-paru dapat identifikasi.

d. Ekstrasi ciri berfungsi sebagai mengetahui ciriciri bercak-bercak putih atau infiltrate yang merupakan ciri dari penyakit pneumonia didalam foto rontgen paru-paru.

e. Diagnosis adalah hasil akhir dari program yang berguna mengetahui apakah citra rontgen yang diteliti terdapat penyakit pneumonia

\section{B. Power-law trans}

Metode yang paling mudah adalah power-law transformation pada grey-level. Pada prinsipnya setiap nilai grey level pada pixel diganti dengan nilai hasil perhitungan formula tertentu. Marilah kita lihat formula power law transformation ini (Khushhal, 2014).

$$
S=C R^{\mathrm{Y}}
$$

\section{Hasil Dan Pembahasan}

A. Input

Pada tahap pertama dilakukan input citra ke dalam aplikasi program untuk mengawali pemrosesan. Adapun data yang diambil adalah data primer dimana data primer merupakan data yang didapatkan langsung dari subyek penelitian. Mekanisme pengambilan citra dilakukan seperti pada Gambar 3.

Berdasarkan Gambar 3 dapat melihat sebuah histogram yang berfungsi untuk mengetahui representasi grafis untuk distribusi citra digital atau menggambarkan penyebaran nilai-nilai intensitas pixel dari suatu citra atau bagian tertentu di dalam citra. Dari sebuah histogram dapat diketahui 
frekuensi kemunculan relatife dari intensitas pada citra, kecerahan, dan kontras dari sebuah citra

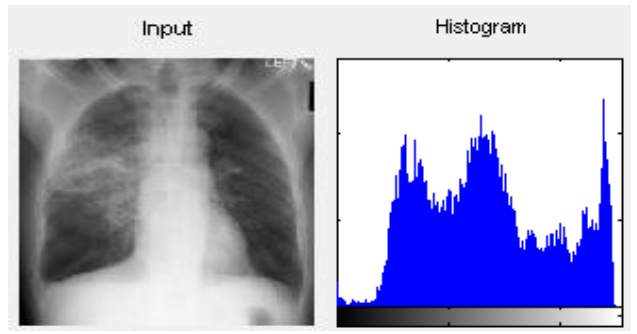

Gambar 3. Proses Input Citra

B. Image Processing

Pada tahap ini proses memperbaiki kualitas citra yang digunakan sebagai bahan utama adalah proses enhancement. Adapun inti pada tahap ini adalah memperbaiki kualitas citra untuk memdiagnosa penyakit pneumonia dengan proses akhir yaitu power law transformation. Proses perbaikan kualitas citra dapat dilihat pada Gambar 4

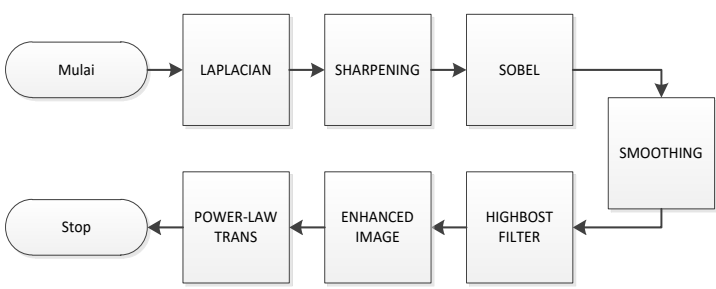

Gambar 4. Prepocessing Image Enhancement

Berdasarkan gambar 4 dapat dilihat sebuah hasil akhir prepocessing power-law trans, dan sebuah histogram yang berfungsi untuk mengetahui hasil dari grey-level power law trans yang sudah di prepocessing. Hasil power law trans dapat dilihat pada Gambar 5.

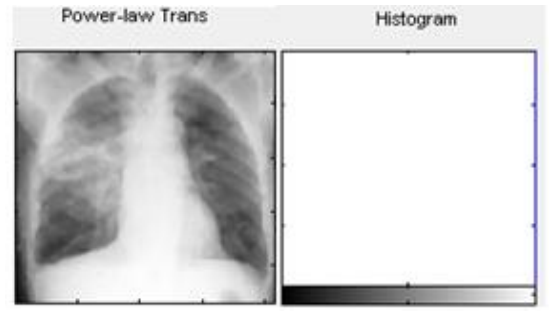

Gambar 5. Hasil Prepocessing Power law trans

Dari Gambar 5 diatas metode Power law trans menggunakan nilai 0.5 untuk grayscale transformasinya. Menggunakan nilai tersebut karena dari hasil seleksi bahwa nilai grayscale 0.5 paling baik.

\section{Segmentasi}

Pada tahap ini segmentasi dilakukan berdasarkan infiltrat dominan menggunakan foto rontgen paru. Sehingga pada penelitian ini Gabor Wavelet berdasarkan infiltrat melakukan segmentasi rontgen menjadi empat komponen. Dimana tulang iga dinyatakan dengan warna dominan abu-abu gelap, alveoli dengan warna dominan putih abu-abu tengah atas, diafragma ke dalam warna putih bawah dan bronkus ke dalam warna putih tengah bawah. Langkah-langkah yang dilakukan pada proses ini adalah sebagai berikut:

a. Citra yang telah mempunyai format jpg, tif, bmp, dikonversikan ke dalam Gabor Wavelet. Metode ini dipilih karena Gabor Wavelet menyediakan pemilihan parameter didasarkan pada empat orientasi yang berpusat, dan sejumlah frekuensi tergantung pada ukuran citra. Gabor menerapkan pendekatan multichannel filtering menggunakan pemilihan frekuensi dan orientasi

b. Pada proses ini Gabor vavelet merupakan salah satu metode yang mampu mensimulasikan karakteristik sistem visual manusia dalam mengisolasi frekuensi dan orientasi tertentu dari citra. Karakteristik ini membuat Gabor Wavelet sesuai untuk aplikasi pengenalan tekstur dalam computer vision

c. Secara spasial, sebuah fungsi Gabor Wavelet merupakan sinusoida yang dimodulasi oleh fungsi Gauss. Citra hasil dalam bentuk grayscale bertujuan untuk lebih mudah dibedakan antara komponen satu dengan yang lain

Didalam penelitian ini segmentasi Gabor Wavelet menggunakan dua puluh empat filter yaitu pada frekuensi $7 \sqrt{ } 2,15 \sqrt{ } 2,31 \sqrt{ } 2,62 \sqrt{ } 2,164 \sqrt{ } 2$ dan $275 \sqrt{ } 2$.

Untuk sudut Orientasi menggunakan 00, 450, 900, 1800. Respon impuls sebuah Gabor Wavelet kompleks dua dimensi dapat dilihat pada Gambar 6.

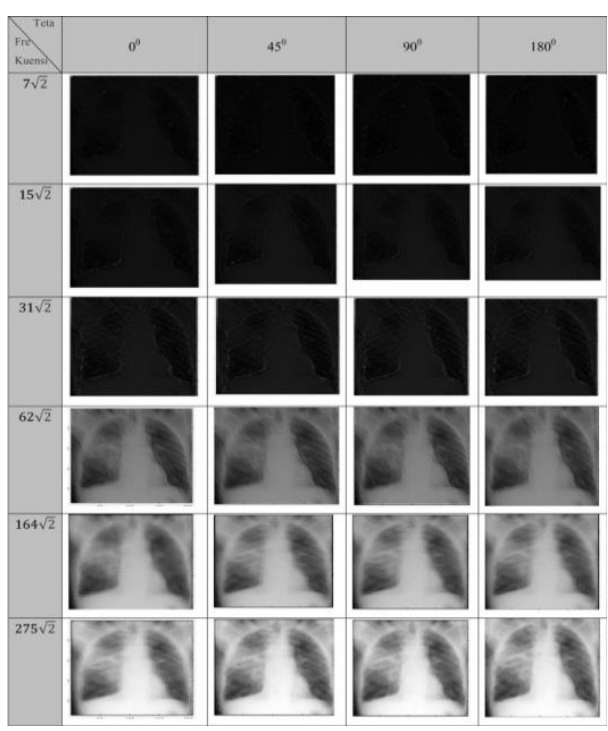

Gambar 6. Citra hasil yang telah disegmentasi

D. Metode Boundary

Metode boundary adalah sistem yang memiliki kemampuan untuk mendeteksi batas objek yang dirujuk oleh citra. Sistem ini diimplementasikan menggunakan metode yang memiliki kemampuan untuk mengikuti objek gambar gerakan, Oleh karena itu metode ini sering digunakan medis, sebenarnya untuk mengamati organ tubuh manusia. Metode ini dikenal sebagai model kontur aktif. Hasil akhir dari 
percobaan ini adalah citra yang dapat menjelaskan batas dari objek citra. Infiltrate penumonia yang telah tersegmentasi mempunyai centroid, equivD, Perimeter dan Roundness. Gambar 7 menunjukkan contoh diagnosis.
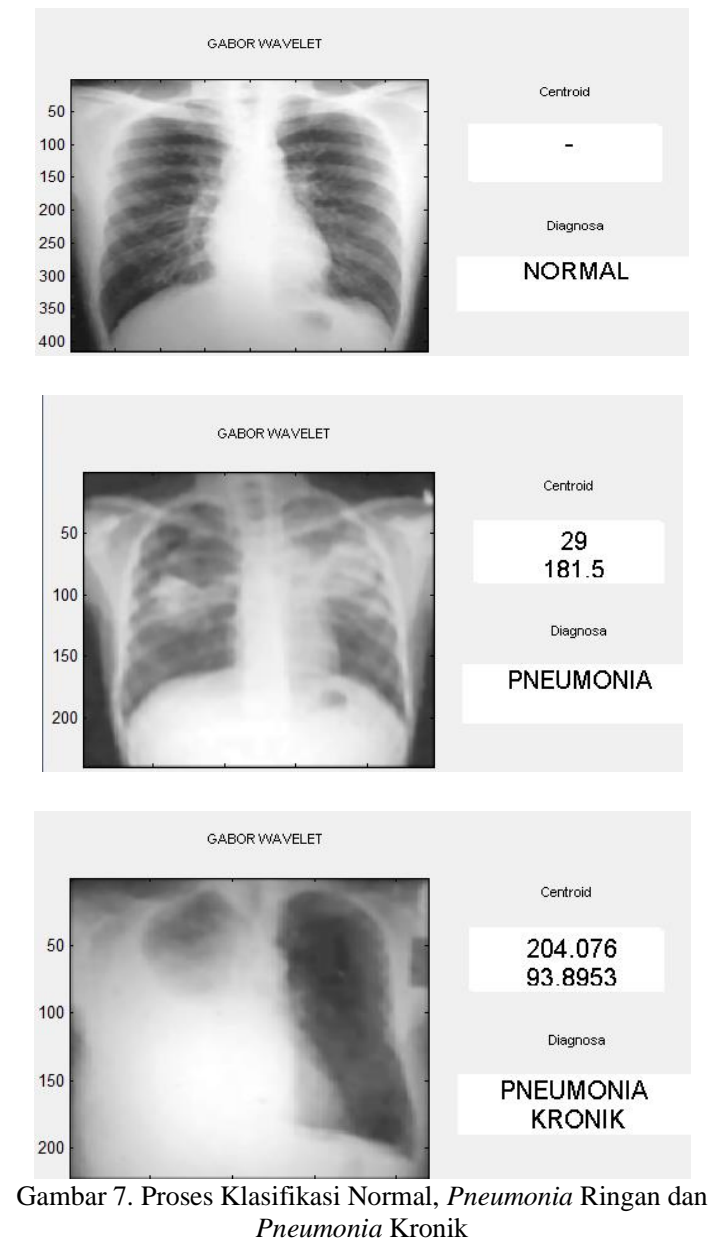

Dari gambar 7 terlihat bahwa frekuensi 388.9 dan orientasi 0 karena di nilai tersebut lebih terlihat daerah paru-paru yang terdampak dari infiltrate sehingga untuk klasifikasi lebih baik. Untuk mengetahui hasil pneumonia di foto rontgen maka dilakukan klasifikasi berdasarkan hasil dari Centroid, EquivD, Perimeter dan Roundness:

a. Centroid yang berfungsi untuk mengetahui koordinat pusat jumlah gumpalan infiltrate.

Pada bagian hasil dan identifikasi penyakit, semua foto rontgen paru-paru telah diklasifikasikan dan hasilnya ditampilkan pada Tabel 1 .

Pada Table 1 dapat dilihat bahwa pneumonia ringan mempunyai diameter relative kecil, karena infiltrate didalam foto rontgen hanya terdapat sedikit sedangkan pneumonia kronik mempunyai diameter relative besar karena infiltrate yang ada didalam foto rontgen hampir menutupi paru-paru.

E. Penilaian dan Identifikasi Penyakit

Setelah citra didefinisikan ke dalam kategori normal dan abnormal, maka tahap berikutnya adalah mengklasifikan citra rontgen pneumonia berdasarkan jenis penyakitnya. Pengelompokan ini berdasarkan standar rontgent paru-paru pneumonia yang telah diusulkan oleh himpunan dokter paru Indonesia.

Klasifikasi ini terinspirasi dari cara dokter menganalisa pneumonia di foto rontgen. Sistem akan mengklasifikasi citra kedalam kelas normal, pneumonia ringan dan pneumonia kronik dengan menggunakan diameter dan perimeter antara jumlah pneumonia ringan dan pneumonia kronik. Klasifikasi di asumsikan sebagai berikut:

Tabel 1. Klasifikasi pneumonia

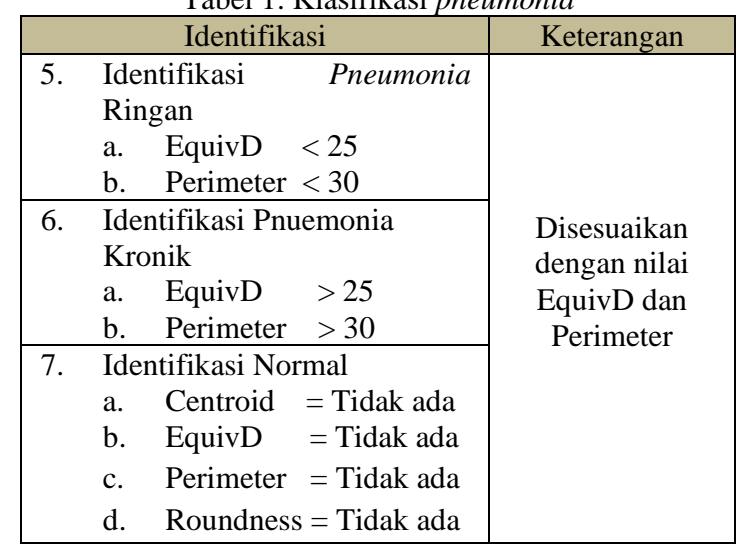

Sumber: Data diolah (2021)

Gambar 7 memperlihatkan identifikasi penyakit pneumonia. Setelah mengelompokkan data berdasarkan boundary, maka dapat dengan mudah jumlah penderita dari sample data setiap jenis penyakit pneumonia. Pada Tabel 2 menunjukkan hasil keakuratan klasifikasi menggunakan sistem

\section{F. Hasil Pengujian}

Pengujian dilakukan pada lima puluh citra dengan spesifikasi yang berbeda.Dari hasil pengujian tersebut, menunjukkan bahwa equivD dan perimeter rata-rata infiltrate ditiap citra yang bernilai dibawah 30 diidentifikasi sebagai penyakit pneumonia. Diidentifikasi pneumonia kronik apabila rata-rata equivD dan perimeter infiltrate diatas 30 . Untuk identifikasi normal apabila centroid, equivD, perimeter dan roundness tidak ada. Hasil perbandingan pengujian pada 50 data foto rontgen ditunjukkan pada tabel

Tabel 2. Hasil Pengujian

\begin{tabular}{|c|c|c|}
\hline $\begin{array}{c}\text { Nama } \\
\text { Citra }\end{array}$ & System & Prediksi \\
\hline 1 & Pneumonia & Pneumonia \\
\hline 2 & Pneumonia & Pneumonia \\
\hline 3 & $\begin{array}{c}\text { Pneumonia } \\
\text { Kronik }\end{array}$ & $\begin{array}{c}\text { Pneumonia } \\
\text { Kronik }\end{array}$ \\
\hline 4 & Pneumonia & Pneumonia \\
\hline 5 & Pneumonia & Pneumonia \\
\hline 6 & Pneumonia & Pneumonia \\
\hline 7 & Pneumonia & Pneumonia \\
\hline
\end{tabular}




\begin{tabular}{|c|c|c|}
\hline & & Kronik \\
\hline 8 & Pneumonia & Pneumonia \\
\hline 9 & $\begin{array}{c}\text { Pneumonia } \\
\text { Kronik }\end{array}$ & $\begin{array}{c}\text { Pneumonia } \\
\text { Kronik }\end{array}$ \\
\hline 10 & Pneumonia & Pneumonia \\
\hline 11 & Pneumonia & Pneumonia \\
\hline 12 & Pneumonia & Pneumonia \\
\hline 13 & Normal & Normal \\
\hline 14 & Normal & Normal \\
\hline 15 & Normal & Normal \\
\hline 16 & Normal & Normal \\
\hline 17 & Normal & Normal \\
\hline 18 & Normal & Normal \\
\hline$\ldots$ & $\ldots$ & $\ldots$ \\
\hline 50 & Normal & Normal \\
\hline
\end{tabular}

Sumber: Data diolah (2021)

Dari hasil pengujian sistem antara sistem yang dibuat dan hasil diagnosis dokter dapat disimpulkan bahwa dari 50 citra yang di uji terdapat satu data uji yang berbeda yaitu pada nama citra tujuh. Sehingga didapatkan rata-rata dari:

Penjelasan TP, TN, FP, dan FN adalah:

a. TP (True Positive), apabila system mengenali ketidak normalan.

b. TN (True Negative), apabila system mengenali normal.

c. FP (False Positive), apabila system mengenali normal sebagai abnormal.

d. FN (False Negative), apabila system mengenali abnormal sebagai normal.

Validitas sistem dinilai dengan cara menghitung nilai TP, TN, FP, dan FN dari tabel dibawah ini.

\begin{tabular}{|c|c|c|c|}
\hline $\begin{array}{c}\text { True } \\
\text { Positif }\end{array}$ & $\begin{array}{c}\text { True } \\
\text { Negatif }\end{array}$ & $\begin{array}{c}\text { False } \\
\text { Positif }\end{array}$ & $\begin{array}{c}\text { False } \\
\text { Negatif }\end{array}$ \\
\hline 33 & 15 & 0 & 2 \\
\hline
\end{tabular}

$$
\begin{gathered}
\text { Sensitivity }=\frac{\mathrm{TP}}{\mathrm{TP}+\mathrm{FN}} \times 100 \%= \\
\frac{33}{33+2} \times 100 \%=94,3 \%
\end{gathered}
$$

Sensitivity dari metode ini adalah 94,3\%. sistem mengenali semua kelainan yang terdeteksi dan dilaporkan. Namun, ada berbagai keberhasilan dalam hal klasifikasi kelas.Berikut specificity mirip dengan True Positif (TP).

Specificity dari metode Boundary diberikan sebagai:

$$
\begin{aligned}
& \text { Specificity }=\frac{T N}{T N+F P} \times 100 \% \\
& =\frac{15}{15+0} \times 100 \%=100 \%
\end{aligned}
$$

Specificity dari sistem ini adalah 100 Ini berarti bahwa sistem menunjukkan $100 \%$ spesifik dalam diagnosis paru-paru selama pengujian sistem.

\section{Kesimpulan}

Pada penelitian ini, diagnosis penyakit pneumonia berdasarkan metode Power-law transformation telah dilakukan. Perbaikan kualitas menggunakan Power-law transformation memberikan hasil peningkatan grey level citra. Ekstrasi ciri Gabor Wavelet yang menjanjikan dapat mengetahui tekstur dari foto rontgen paru-paru. Untuk dapat membedakan normal, pneumonia ringan dan kronik digunakanlah klasifikasi menggunakan boundary yang didalamnya terdapat centroid, equivd, perimeter dan roundness. Dalam identifikasi infiltrate pneumonia harus mendapatkan perhatian dalam mengetahui ciri-cirinya, karena infiltrate pneumonia dengan tuberculosis mempunyai kemiripan hampir sama, maka dalam penelitian ini dibantu oleh dokter yang memberikan pengetahuan mengenai perbedaan antara tuberculosis dan pneumonia, sehingga identifikasi penyakit pneumonia citra rontgen sesuai dengan hasil yang diharapkan. Dari hasil pengujian tersebut, menunjukkan bahwa equivD dan perimeter rata-rata infiltrate ditiap citra yang bernilai dibawah 30 diidentifikasi sebagai penyakit pneumonia. Diidentifikasi pneumonia kronik apabila rata-rata equivD dan perimeter infiltrate diatas 30. Untuk identifikasi normal apabila centroid, equivD, perimeter dan roundness tidak ada. Validitas sistem dinilai dengan cara menghitung nilai TP, TN, FP, dan FN sehingga di dapatkan Sensitivity dari metode ini adalah 94,3\% sistem mengenali semua kelainan yang terdeteksi dan dilaporkan. Namun, ada berbagai keberhasilan dalam hal klasifikasi kelas. Berikut specificity mirip dengan True Positif (TP). Untuk Specificity dari sistem ini adalah $100 \%$. Ini berarti bahwa sistem menunjukkan $100 \%$ spesifik dalam diagnosis paru-paru selama pengujian sistem.

\section{Daftar Pustaka}

Kumar Deepak, A G Ramakrishnan. 2013. "Powerlaw transformation for Enhanced Recognition of Born-Digital Word Images". Medical Intelligence and Language Engineering Laboratory Department of Electrical Engineering Indian Institute of Science Bangalore, India.

Perhimpunan Dokter Paru Indonesia. 2004. "Pneumonia Komuniti".

Rahmadwati 2012. "Gabor Wavelet". University Brawijaya, Indonesia.

Samir Kumar Bandyopadhyay. 2012. "A Method for Lung Boundary Detection". University of Calcutta, 92 A.P.C. Road, Kolkata - 700009, India.

Ya-Lin Song, Yang Yang. 2010. "Localization Algorithm and Implementation for Focal of Pulmonary Tuberculosis Chest Image". Computing Center ,Henan University Kaifeng,P.R.China.

Yuwono Bambang. 2011. "Image Smoothing Menggunakan Mean Filtering, Median Filtering, Modus Filtering Dan Gaussian 
Filtering“. Jurusan Teknik Informatika UPN "Veteran", Yogyakarta.

Burke A Cunha, MD. Nosocomial Pneumonia.http://emedicine.medscape.com/arti cle/234753-overview (accessed 26 September 2017).

Data Rekam Pasien RSSA."Citra Rontgen Mengandung Penyakit Pneumonia”.Malang, 2014.

Jassim A Firas.2013. “A Novel Steganography Algorithm to Hide a Grayscale BMP Image in Two Grayscale BMP Images for Dual Secrecy". Computer Information Systems Department. Irbid National University, Jordan.

Jindal Khushhal, Kriti Gupta, Manan Jain, Manmohan Maheshwari. 2014. "BioMedical Image Enhancement Based On Spatial Domain Technique". Department of CSE \&IT ITM University Gurgaon, India.

Liu Vincent Mark P Clark, Mark Mendoza, Ramin Saket, Marla N Gardner, Benjamin J Turk and Gabriel J Escobar. 2013. "Automated Identification Of Pneumonia In Chest Radiograph Reports In Critically Ill Patients".BMC Medical Informatics and Decision Making.

Masfran dkk, 2012, Segmentasi Tepi Citra CT Scan Paru-paru Menggunakan Metode Chain Code dan Operasi Morfologi”. Jurnal Teknik Informatika, Vol 1 September 2012.

Patra Joyjit, Himadri Nath Moulick, Arun Kanti Manna. 2013. "Medical Image Processing in Nuclear Medicine and Bone Arthroplasty".Institute Of Engineering And Management, India.

Rahmadewi Reni dan Kurnia Rahmadi, 2016" Klasifikasi Penyakit Paru Berdasarkan Citra Rontgen Dengan Metoda Segmentasi Sobel'Jurnal Nasional Teknik Elektro, Vol 5, No. 1, Maret 2016.

Sutoyo T, Mulyanto E, Suhartono V Nurhayati O D, dan Wijanarto. (2009). "Teori Pengolahan Citra Digital”, Andi. Yogyakarta Lembaga 